\title{
KEDUDUKAN AGAMA DAN KEBEBASAN BERKEYAKINAN DALAM KONTEKS NEGARA HUKUM PANCASILA
}

Alwiyah Sakti Ramdhon Syah R

Email: ramdhansyah44@gmail.com

\begin{abstract}
This study aims to analyze how the position of religion position within the constitutions of Indonesia and it's implications for religious freedom in Negara Hukum Pancasila (rule of law), as well as recognition and protection of law against religion and religious activities in the constitution of Indonesia. Article 29 paragraph (1) declare about the state based on the divinity, and paragraph (2) that the state guarantees the independence of every Indonesian citizen for embracing and worshiping according to his belief. Explanation on article 1 of act No. 1/PNPS/ of 1965 states the existence of legal protection against the official religions embraced by the Indonesian population (Islam, Christian, Catholic, Hindu, Buddhist, Kong $\mathrm{Hu} \mathrm{Chu}$ ) and other beliefs as long as they obey the Constitutions and the laws. However, in the domain of the Negara Hukum Pancasila, there are still found the intervention of religion and religiosity in the eingenritching form by society and even onrechtsmatig overheids daads form by the government. In a Negara Hukum Pancasila, everything must be settled by law, with consideration that the major fortune in a law constitutional not only in the prestige of the law itself, but also against the sovereignty of the people, particularly the issue of human rights.
\end{abstract}

Keywods: Agama, Kebebasan, Negara Hukum

\begin{abstract}
ABSTRAK
Penelitian ini bertujuan untuk menganalisis bagaimana kedudukan agama dalam ketatanegaraan Indonesia dan implikasinya terhadap kebebasan beragama dalam konteks Negara Hukum Pancasila, serta pengakuan dan perlindungan hukum terhadap agama dan kegiataan keberagamaan dalam ketatanegaraan Indonesia. Pasal 29 ayat (1) menyebut negara berdasarkan Ketuhanan, dan ayat (2) bahwa negara menjamin kemerdekaan tiap-tiap penduduk Indonesia memeluk dan beribadat sesuai keyakinannya. Penjelasan Pasal 1 UU Nomor 1/PNPS/ Tahun 1965 menyebutkan adanya perlindungan hukum terhadap agama-agama resmi yang dianut penduduk Indonesia (Islam, Kristen, Khatolik, Hindu, Budha, Kong $\mathrm{Hu} \mathrm{Chu}$ ) juga aliran kepercayaan lainnya sepanjang tunduk terhadap Konstitusi dan Peraturan Perundang-undangan. Namun demikian, dalam domain Negara Hukum Indonesia masih saja ditemukan adanya intervensi terhadap agama dan keberagamaan dalam bentuk eigenritching oleh masyarakat bahkan onrechtsmatig overheidsdaads oleh pemerintah.Dalam negara hukum, segala sesuatu mesti diselesaikan dengan hukum, dengan pertimbangan bahwa daulat utama dalam suatu negara hukum bukan hanya ada pada wibawa hukum itu sendiri, tetapi juga terhadap kedaulatan rakyat, khususnya masalah HAM.
\end{abstract}

Kata Kunci: Agama, Kebebasan, Negara Hukum 


\section{PENDAHULUAN}

Indonesia adalah negara hukum, sebagaimana tertuang dalam Pasal 1 ayat (3) UUD NRI 1945.Sebelum perubahan, kedudukan negara hukum yang dianut Indonesia bercirikan tipe negara hukum civil law atau yang biasa dikenal dengan istilah rechtstaat, dan bukan dengan kekuasaan atau machtstaat. Akan tetapi setelah perubahan, tidak disebutkan secara eksplisit dalam redaksi Pasal, apakah negara hukum Indonesia bertipe civil law system (rechtstaat) ataupun bertipe common law system (rule of law). Belakangan kemudian ahli hukum hukum Indonesia sepakat merumuskan suatu paham negara hukum yang memiliki kedudukan dan wibawa yang sama seperti tipe-tipe negara hukum di dunia, yang kemudian dikenal dengan istilah Negara Hukum Pancasila (Atmadja, 2015:149).

Karakteristik negara-negara yang berlandaskan hukum secara mainstream diketahui melalui adanya suatu wetmatig bestuur dan juga due procees of law ataupun juga memiliki unsur peradilan administrasi. Adapun hal yang tak kalah pentingnya dalam unsur sebuah negara hukum yakni perlindungan HAM terhadap semua warga negara tanpa memandang latar belakang agama, budaya, ras, suku, dan sebagainya. Dalam kajian-kajian ilmiah, diketahui bahwa HAM merupakan suatu obyek yang mesti mendapatkan pengakuan dan perlindungan dikarenakan kedudukannya yang erat dengan keberadaan manusia itu sendiri. Terbukti dalam Konstitusi Indonesia, mengenai HAM diatur dalam Bab XA UUD NRI 1945 sebagai perwujudan dari daulat rakyat yang sebelumnya juga tertuang pula dalam Pasal 1 ayat (2).

Salah satu unsur terkait dengan HAM ialah mengenai kedudukan agama dan keberagamaan.Indonesia adalah negara dengan rakyat yang pada umumnya merupakan masyarakat religius, sehingga aktifitas kehidupan masyarakat Indonesia tidak bisa dilepaskan dari unsur keagamaan sebagai salah satu hak dan kebutuhan yang sifatnya otonom dari entitas bangsa Indonesia 
itu sendiri. Respon negara terhadap keberadaan aktifitas keagamaan masyarakat Indonesia dapat dilihat melalui dibentuknya lembagalembaga yang khusus mengatur urusan masyarakat Indonesia, yang berkaitan dengan keagamaan seperti misalnya Kementerian Agama, ataupun juga Peradilan Agama yang berada dalam lingkungan Mahkamah Agung.

Dalam Pasal 29 ayat (2) UUD NRI 1945 disebutkan bahwa "Negara menjamin kemerdekaan tiap-tiap penduduk untuk memeluk agamanya masing-masing dan untuk beribadat menurut agamanya dan kepercayaannya itu”. Hal ini merupakan sebuah konsekuensi dari ayat sebelumnya yakni ayat (1) yang menyebutkan "Negara berdasar atas Ketuhanan Yang Maha Esa”. Kedudukan Agama menurut Penjelasan Pasal 1 UU Nomor 1/PNPS/ Tahun 1965 menyebutkan bahwa umumnya agama-agama yang dianut masyarakat Indonesia dan mendapat perlindungan hukum adalah Islam, Kristen, Khatolik, Hindu, Budha, dan Kong $\mathrm{Hu} \mathrm{Chu}$ (Konfusius). Namun menurut
Penjelasan Pasal ini, tidak tertutup kemungkinan agama atau aliran lain juga diberikan perlindungan oleh negara sepanjang tunduk pada ketentuan dengan hukum yang berlaku di Indonesia.

Akan tetapi, sekalipun adanya garansi dan jaminan perlindungan hukum oleh Konstitusi dan Peraturan perundangan terkait aktifitas keberagaman kepada masyarakat, kenyataannya persoalan yang menyangkut masalah agama dan keagamaan masih terasa belum mengakomodir seluruh aspirasi masyarakat Indonesia yang akibatnya terjadi beberapa varian tafsir secara subyektif mengenai kedudukan agama-agama di Indonesia. Masalah ini khususnya menyangkut kata "Ketuhanan" dalam Pasal 29 UUD NRI 1945.

Menurut Jimly Asshiddiqie, kata "Ketuhanan" hingga kini belum diketemukan kesepahaman yang Universal. Ashiddiqie kemudian membagi 4 (empat) kemungkinan klasifikasi hubungan antara Tuhan dan Agama dalam praktik di dunia dan di Indonesia yakni, Pertama, pengertian bertuhan dipandang 
identik dengan beragama.Kedua, pengertian bertuhan tidak identik dengan agama.Ketiga, aliran yang percaya kepada aliran agama tertentu, tetapi tidak mengenal konsep ketuhanan.Keempat, tidak percaya kepada Tuhan dan juga agama (Asshiddiqie, 2015:28).

Klasifikasi yang terakhir yakni yang biasa dikenal dengan paham atheism, jelas tidak sesuai dengan tujuan dibentuknya negara Indonesia. Menurut Tahir Azhary (Azhary, 2003:93), sesuai dengan sila Pertama Pancasila dan Pasal 29 UUD NRI 1945 jelas bahwa atheism tidak dapat diterima di Indonesia sehingga dengan sendirinya tidak mendapat pengakuan dan perlindungan hukum di Indonesia.

Yang menarik adalah bila diperhatikan bagaimana pidato Bung Karno menyangkut masalah "Ketuhanan". Dalam pidatonya, Bung Karno menyebut bahwa "Bukan saja bangsa Indonesia bertuhan, tetapi hendaklah tiap-tiap orang Indonesia bertuhan...."(Kaelan, 2013:181) yang apabila dikaitkan dengan klasifikasi oleh Jimly Asshiddiqie, kesan yang muncul ialah intinya bertuhan, tak menjadi soal apakah beragama ataukah tidak.

Dalam hal ini apa yang disebutkan oleh Jimly Asshiddiqie pada klasifikasi pertama dan kedua sesuai dengan pidato Bung Karno. Disisi lain UUD NRI 1945 tidak ada satupun Pasal yang secara spesifik menyebut bahwa "Ketuhanan" negara Indonesia dipahami identik dengan salah satu dari klasifikasi tersebut, ataupun Tuhan yang berdasarkan pada suatu agama tertentu.

Meskipun Penjelasan Pasal 1 UU Nomor 1/PNPS/ Tahun 1965 menyebut keberadaan agama-agama resmi yang disebutkan, dan memberi kemungkinan adanya pengakuan dan perlindungan terhadap aliran kepecayaan lainnya sepanjang tunduk dengan hukum yang berlaku di Indonesia, akan tetapi perihal masalah agama dan keberagamaan belum sepenuhnya selesai dan selalu saja menjadi persoalan yang hangat pada kalangan masyarakat terlebih lagi pada kalangan ahli hukum di Indonesia. Masalah ini diperparah oleh keadaan cendikiawan di 
Indonesia yang masih memandang agama sebagai sesuatu yang "sensitif" untuk dibahas.Padahal dalam kenyataannya, kebutuhan perihal kejelasan kedudukan agama dan ketuhanan semakin hari bertambah peminatnya.

Timbulnya kasus kekerasaan atas nama agama ataupun perilaku eigenritching oleh masyarakat terhadap kegiatan keberagamaan juga ada yang memakan korban. Sebut saja soal tragedi Sampang Madura, dan juga soal aliran Sunda Wiwitan.Dan masih segar pula dalam ingatan kita soal SKB 3 (tiga) menteri tentang pelarangan kegiatan aliran JAI (Jaringan Ahmadiyyah Indonesia) yang buntutnya Pemerintah Daerah setempat memberlakukan suatu Keputusan (beschikking) yang melarang kegiatan keagamaan aliran yang bersangkutan.

Padahal, dalam Undangundang Pemerintah Daerah disebutkan bahwa Pemerintah tidak boleh mengintervensi kehidupan beragama, melainkan mengatur dan membuka ruang mediasi bila terdapat sengketa mengenai agama. Disisi lain, SKB tidak dikenal dalam hierarki peraturan perundangundangan. Bila menteri membuat keputusan, seharusnya dengan pertimbangan Peraturan Pemerintah dan Undang-undang.

\section{METODE PENELITIAN}

Metode penelitian yang digunakan dalam pengumpulan data merupakan hal yang penting dalam mengumpulkan bahan materi penelitian tesis.Dalam penelitian ini, metode penelitian yang digunakan adalah sebagai berikut.

1. Tipe Penelitian.

Tipe penelitian yang dipakai dalam penulisan tesis ini adalah penelitian hukum normatif-yuridis. Penelitian ini merupakan penelitian yang mengacu pada norma hukum segala peraturan perundangundangan yang relevan dengan judul tesis ini. Penelitian tesis ini menggunakan pendekatan kualitatif yaitu penelitian terhadap peraturan perundang-undangan yang berkaitan dengan agama, politik hukum, pancasila, dan ketatanegaraan.

2. Sifat Penelitian. 
Sifat penelitian yang digunakan dalam penulisan ini adalah bersifat deskriptif-analitis.Deskriptif-analitis merupakan metode yang dipakai untuk menggambarkan suatu kondisi atau keadaan yang sedang terjadi atau berlangsung yang tujuannya agar dapat memberi data seteliti mungkin mengenai obyek penelitian sehingga mampu menggali hal-hal yang bersifat ideal, kemudian dianalisis berdasarkan teori hukum atau peraturan perundang-undangan yang berlaku.Dalam penelitian ini hal tersebut dilakukan dengan menguraikan masalah kedudukan agama dalam konteks Politik Hukum pancasila dan Ketatanegaraan.

3. Jenis dan Sumber Data.

Data penelitian yang digunakan dalam penelitian tesis ini terdiri atas :

a. Bahan hukum primer.

Yaitu bahan-bahan hukum mengikat yang terdiri dari peraturan perundangundangan dan kebiasaan. Dalam hal ini penulis menggunakan UUD NRI Tahun 1945; UU Nomor 1 /PNPS/ Tahun 1965; UU Nomor 39 Tahun 1999 tentang Hak Asasi Manusia; Keppres Nomor 6 Tahun 2000 tentang Pencabutan Instruksi Presiden Nomor 14 Tahun 1967 tentang Agama, Kepercayaan, dan Adat Istiadat Cina, dan Putusan Mahkamah Konstitusi.

b. Bahan Hukum Sekunder Yaitu buku-buku, maupun tulisan-tulisan ilmiah seperti skripsi, tesis, desertasi, jurnal, artikel, ataupun hasil seminar yang mengulas tentang Pancasila, agama, dan, hukum tata negara yang terkait dengan penelitian tesis ini.

c. Bahan Hukum Tersier Yaitu petunjuk yang memberikan penjelasan mengenai bahan hukum primer dan sekunder antara lain yakni, kamus-kamus, ensiklopedia, majalah, surat kabar, dan sebagainya.

4. Teknik Pengumpulan Data

Metode yang digunakan dalam pengumpulan data untuk penelitian ini adalah dengan Penelitian 
Kepustakaan.Metode pengumpulan bahan dilakukan dengan penelitian kepustakaan (library research). Studi ini dilakukan dengan meneliti dokumen-dokumen yang ada yaitu dengan mengumpulkan data dan informasi yang baik berupa buku, karangan ilmiah, peraturan perundang-undangan dan bahan tertulis lainnya yang berkaitan dengan penelitian ini, yaitu dengan cara mencari, mempelajari, mencatat serta menginterpretasikan hal-hal yang berkaitan dengan obyek penelitian.

\section{Teknik Analisis Data}

Analisis data dalam penelitian ini menggunakan metode analisis kualitatif.Analisis data kualitatif dilakukan terhadap data yang tidak dapat dikuantifikasikan, yakni semua bahan hukum primer, sekunder, dan tersier, demikian juga bahan pustaka, jurnal ilmiah hukum, dan peraturan perundang-undangan yang berhubungan dengan masalah Agama dan Politik hukum Pancasila.

Tahapan yang dilakukan dalam analisis ini adalah :

1. Melakukan inventarisasi terhadap semua regulasi atau peraturan perundangundangan yang menyangkut agama, politik hukum pancasila,dan

ketatanegaraan yakni Undang-undang Dasar, Undang-undang, Peraturan Presiden, Keputusan Presiden, Keputusan Menteri, Putusan Mahkamah Konstitusi, dan sebagainya.

2. Melakukan penelusuran terhadap berbagai regulasi sebagaimana disebut diatas dengan melakukan pengamatan secara cermat terhadap substansi atau isi masing-masing regulasi.

3. Hasil penelusuran dan pengamatan terhadap berbagai regulasi selanjutnya akan dipaparkan secara deskriptif sebagai bentuk hasil penelitian dan diikuti rekomendasi penelitian.

\section{Pembahasan}

1. Sekilas Tentang Negara Hukum Pancasila 
Dalam kajian ketatanegaraan apabila disebutkan kalimat "Negara Hukum", maka dengan mudah dipahami secara aksiomatis tentang konsep Rechtstaat ataupun Rule of law, selain konsep atau tipe negara hukum lainnya seperti Socialist Legality dan Nomokrasi Islam.Sebenarnya masih ada tipe negara hukum lainnya seperti Negara hukum Cina, Hukum Hindu, Monarki Konstitusional,Negara Hukum Pancasila, dan sebagainya.

Ide tentang negara hukum secara embrionik disinyalir berasal dari Yunani ketika Plato menulis sebuah karya yaitu Nomoi sebagai tulisan ketiganya setelah sebelumnya iaPolitea dan Politicos yang belum muncul istilah negara hukum (Ridwan HR， 2006:2).Dalam Nomoiplato mengemukakan bahwa penyelenggaraan negara yang baik ialah yang didasarkan pada pengaturan (hukum) yang baik. Gagasan tentang negara hukum ini semakin tegas ketika didukung oleh muridnya Aristoteles yang menuliskan buku berjudul Politea.

Menurut Aristoteles, suatu negara yang baik ialah negara yang diperintah dengan Konstitusi dan berkedaulatan hukum. Menurutnya ada tiga unsur pemerintahan yang berkonstitusi yakni (1) Pemerintahan dilaksanakan untuk kepentingan umum; (2) Pemerintahan dilaksanakan menurut hukum yang berdasarkan pada ketentuanketentuan umum, bukan hukum yang dibuat secara sewenang-wenang; dan (3) Pemerintahan berkonstitusi berarti pemerintahan yang dilaksanakan atas kehendak rakyat, buka oleh paksaan pemerintahan despotik.

Dalam konsep negara hukum Rechtstaat, menurut F.J Stahl ada 4 (empat) unsur pokok penting yakni, (1) Pengakuan dan Perlindungan terhadap hak asasi manusia; (2) Trias Politica; (3) Pemerintahan berdasarkan Undang-undang (wetmatig bestuur); dan (4) Peradilan administasi negara. Sedangkan Rechtstaat menurut Scheltema unsurunsurnya yakni, (1) Kepastian Hukum; (2) Persamaan; Demokrasi; dan (4) Pemerintahan yang melayani kepentingan umum.

Sementara itu dalam konsep negara hukum Rule of Law, menurut 
A.V Dicey 3 (tiga) unsur utama yakni, (1) Supremasi Hukum (supremacy of law); (2) Persamaan didepan hukum (equality before the law); dan (3) Konstitusi didasarkan pada hak-hak perorangan (the constitutions based on individual rights).

\section{Konsep Negara Socialist}

Legality unsur utamanya yakni (1) Supremasi hukum (supremacy of law); (2) Asas Legalitas (Principle of legality); (3) Kebebasan Hakim (Independence judge); dan (4) Perlindungan Hak Asasi manusia (Protection of human rights). Sementara itu dalam Warsawa Culloqium, unsur-unsur Socialist legality yakni (1) Perwujudan sosialisme; (2) Hukum sebagai alat politik dibawah ideologi sosialisme; dan (3) pengutamaan kewajiban kepada negara daripada perlindungan HAM (Atmadja, 2015: Op.cit 148). Menurut beberapa ahli, supremacy of law dalam konsep Socialist Legality hanyalah "slogan" semata karena pada dasarnya pada konsep ini hukum disubordinasi oleh kepentingan sosialisme.
Prinsip konsep Nomokrasi Islam menurut Tahir Azhary ditandai dengan 9 (Sembilan) unsur yakni (1) Prinsip kekuasaan sebagai amanah; (2) Prinsip Musyawarah; (3) Prinsip keadilan; (4) Prinsip persamaan; (5) Prinsip pengakuan dan perlindungan setiap hak-hak asasi manusia; (6) Prinsip peradilan bebas; (7) Prinsip perdamaian; (8) Prinsip kesejahteraan; dan (9) Prinsip ketaatan rakyat (Azhary, 2003: Loc.cit 85).

Dalam pasal 2 UU Nomor 12 Tahun 2011 disebutkan bahwa Pancasila merupakan segala sumber hukum Negara. Hal ini berarti bahwa Negara hukum di Indonesia berciri esensial khas Indonesia, yang setara dengan konsep Negara hukum lainnya seperti konsep Rechtstaat, Rule of Law, Socialist Legality, Nomokrasi Islam, dan lain sebagainya.

Menurut Oemar Senoadji, Negara Hukum Pancasila memiliki ciri-ciri khas Indonesia. Pancasila dipandang sebagai dasar pokok (grundnorm) hukum Indonesia dengan ciri-ciri yakni, (1) Hak asasi sebagai unsur esensial Negara hukum 
sesuai penghormatan kepada martabat manusia (human dignity) ditekankan pada keseimbangan perlindungan kepentingan individu dan masyarakat dengan cerminan hukum adat Indonesia;

Kebebasan beragama sesuai dengan sila Ketuhanan Yang Maha Esa yang dijamin Konstitusi. Kendati demikian, sila ini menolak dengan tegas propaganda anti agama dan atheism seperti di Negara-negara barat; (3) Pengakuan dan pengembangan hak-hak sosial, ekonomi, dan kultural dalam suatu Negara hukum; dan (4) Kondisi keadaan darurat Negara harus benarbenar terkualifikasi dalam hukum.

Menurut

Soediman

Kartohadiprodjo, pemikiran Negara Hukum Pancasila bercirikan, (1) Jiwa kekeluargaan; (2) Musyawarah mufakat berlandaskan hukum adat; (3) Melindungi rakyat dari tindakan pemerintah yang sewenang-wenang; dan (4) Mengutamakan tugas dan tanggungjawab bagi lembagalembaga Negara dan bukan mengutamakan kekuasaan.

Menurut Padmo Wahjono, Negara Hukum Pancasila bertolak dari asas kekeluargaan sebagaiman tercantum dalam pasal 33 ayat 1 UUD NRI 1945 yang bercirikan, (1) Mengutamakan kepentingan banyak orang, namun harkat martabat manusia tetap dihargai;

Mengutamakan kemakmuran rakyat dan bukan kemakmuran individu; (3) Orang perseorangan berusaha sepanjang tidak mengenai hajat hidup orang banyak; (4) Fungsi hukum pengayoman; dan Mengakui eksistensi hukum tidak tertulis selain yang tertulis.

Menurut Philipus M. Hadjon dalam desertasinya berjudul "Perlindungan Hukum Bagi Rakyat" bercirikan, (1) Keserasian hubungan antara pemerintah dan rakyat berdasarkan asas kerukunan sosial; (2) Hubungan fungsional dan proposional antara kekuasaan Negara; (3) Prinsip menyelesaikan sengketa secara musyawarah dan peradilan merupakan sarana terakhir; dan (4) Kesimbangan antara hak dan kewajiban.

Menurut Tahir Azhary, negara hukum Pancasila memiliki ciri-ciri (1) Hubungan yang erat antara Agama dan Negara; (2) Bertumpu 
pada Ketuhanan Yang Maha Esa; (3)

Kebebasan beragama dalam arti positif; (4) Atheisme tidak dibenarkan dan komunisme dilarang; dan (5) Asas keluarga dan kerukunan. Sedangkan unsur utama negara hukum Pancasila yakni (1) Pancasila; (2) MPR; (3) Sistem Konstitusi; (4)Persamaan; dan (5) Peradilan bebas (Azhary, 2003: Loc.cit 102).

Dari uraian diatas dapat diketahui bahwa unsur negara hukum Pancasila adalah (1) Berketuhanan Yang Maha Esa; (2) Asas Kekeluargaan; (3) Pengakuan dan Perlindungan HAM; (4) Musyawarah Mufakat; (5) Mengakui hukum yang tidak tertulis disamping hukum yang tertulis; (6) Toleransi; dan (7) Pengakuan hak-hak sosial, ekonomi, dan kultural dalam suatu negara hukum.

Kaitannya dengan persoalan kemerdekaan dan kebebasan beragama dalam konsep Negara Hukum Pancasila, jelas bahwa hak beragama adalah hak asasi yang tak dapat dikurangi sedikitpun (Pasal 28I ayat 1 UUD NRI 1945, dan Pasal 4 UU Nomor 39 Tahun 1999).
Sebagaimana penjelasan Pasal 1 UU Nomor 1 PNPS Tahun 1965 selain 6 agama resmi yang dianut penduduk Indonesia, keberadaan agama-agama lain juga mendapat perlindungan yang sama berdasarkan Pasal 29 ayat 2 UUD NRI 1945, sepanjang tunduk kepada peraturan perundanganundangan Indonesia.

2. Kedudukan Agama dan Keberagamaan, Pengakuan dan Perlindungan Terhadap Kebebasan Beragama dalam Negara Hukum Pancasila

Merupakan hal yang telah maklum diantara cendikiawan ataupun peminat kajian ketatanegaraan Indonesia bahwa niat awal The Founding Father's bangsa Indonesia sepakat membangun negara Indonesia, selain untuk sebaik-baiknya menata kehidupan rakyat Indonesia, adalah juga untuk membangun bangsa dan negara yang bertuhan. Unsur ketuhanan dalam Konsitusi Indonesia telah ada semasa sidang-sidang dalam forum BPUPKI dan PPKI, yang terus berlanjut hingga pada forum Konstituante (Mahfud MD, 2009:5).Terlepas dari bagaimana alur perdebatan yang 
terjadi semasa itu, yang pasti mayoritas bahkan semua bangsa Indonesia sepakat membentuk negara yang memiliki unsur "Ketuhanan".

Dalam Pasal 29 ayat (1) dan

(2) UUD NRI 1945 disebutkan bahwa negara berdasarkan Ketuhanan, dan menjamin kemerdekaan dan kebebasan beragama bagi tiap-tiap pemeluknya. Hal ini sesuai dengan isi Pancasila terutama sila 1 (pertama) yakni "Ketuhanan Yang Maha Esa" sebagai batang tubuh UUD NRI 1945.Kusnardi \& Harmaily Ibrahim melanjutkan, ketentuan ini menjadi dasar bagi Pemerintah dan alat perlengkapan negara lainnya dalam mengatur kegiataan keberagamaan bagi penduduk Indonesia (Kusnardi, et.al, 1976:103).

Penjelasan Pasal 1 UU Nomor /PNPS/ Tahun 1965 menyebutkan bahwa negara mengakui dan melindungi 6 (enam) yang dipeluk oleh penduduk Indonesia (Islam, Kristen, Khatolik, Hindu, Budha, dan Kong $\mathrm{Hu} \mathrm{Chu}$ ), dan juga menjamin keberadaan keyakinan lainnya sepanjang tunduk dengan Konstitusi dan peraturan perundangan- undangan. Hal ini sesuai juga dengan TAP MPRS Nomor III/MPRS/1960, lampiran A, Biidang 1, angka 6, dengan kata-kata "Kegiatan Keberagamaan" dimaksudkan segala macam kegiatan yang bersifat keagamaan, misalnya menamakan suatu aliran sebagai agama, mempergunakan istilah dalam menjalankan atau mengamalkan ajaran-ajaran kepercayaan ataupun melakukan ibadahnya dan sebagainya. Pokok-pokok ajaran agama diketahui oleh Departemen ajaran agama yang untuk itu mempunyai alat-alat/cara-cara untuk menyelidikinya.

Disisi lain, Mahfud MD menjelaskan jika dilihat dari hubungan antara Agama dan Negara, Indonesia dengan sistem hukum Pancasila yang prismatik bukanlah negara agama (teokrasi) yang menjadikan suatu agama sebagai agama resmi negara, dan pun juga buan negara sekuler yang mengabaikan agama-agama yang dianut penduduknya (Mahfud MD, 2010:29). Mahfud melanjutkan, Indonesia adalah sebuah religious nation state yang menghormati dan 
membina semua agama yang dianut oleh rakyatnya sepanjang berkemanusiaan dan berkeadaban.

Pelayanan negara terhadap para pemeluk agama dalam hal peribadatan haruslah adil dan tidak memandang besar atau kecilnya jumlah penganut. Negara harus membina kehidupan beragama warganya tanpa ikut mengatur cara peribadatannya (Mahfud MD, 2010: Op.cit 30).Pada saat yang sama semua warga negara harus menyadari bahwa memeluk agama adalah sebuah Hak Asasi yang tak boleh dikurangi sedikitpun dan diganggu oleh siapapun.

Kaitannya dengan asas Ketuhanan dalam sila 1 (kesatu) Pancasila, menarik apabila disimak uraian dari Prof. Kaelan MS. Menurut Kaelan, Pancasila merupakan causa matrealis, yakni nilai-nilai yang telah ada pada bangsa Indonesia sejak zaman dahulu kala (Kaelan, 2013: Loc.cit 205). Rumusan Ketuhanan Yang Maha Esa dalam Pembukaan UUD NRI 1945 memberikan sifat yang khas bagi negara Indonesia yaitu bukan sebagai negara sekuler, ataupun negara dengan agama tertentu.

Kaelan melanjutkan, negara tidak bisa memaksakan agama dan kepercayaan terhadap Tuhan Yang Maha Esa karena hal itu merupakan suatu keyakinan bathin yang tercermin dalam hati sanubari penganutnya dan tidak dapat dipaksakan. Dengan perkataan lain negara menjamin kemerdekaan setiap warganya untuk memeluk dan beribadat menurut kepercayaan agamanya tersebut.

Dalam menjalankan hak dan kewajiban, warga negara secara tidak sadar tengah melakukan perbuatan hukum (rechthandeling) dan hubungan hukum (rechtbetrkkingen)(Soeroso, 1995:29).Ketika melakukan perbuatan hukum ataupun hubungan hukum, masing-masing masyarakat tertentu memiliki kepentingan yang berbeda-beda yang kadang-kadang saling berhadapan atau berlawanan.Untuk mengatasi ketegangan dan konflik maka hukum tampil untuk mengatur dan melindungi kepentingan tersebut sesuai dengan aturan-aturan 
hukum.Hal ini dinamakan perlindungan hukum.Namun pada dasarnya perlindungan hukum selalu didahului dengan adanya suatu pengakuan baik secara de facto ataupun de jure.

Perlindungan hukum merupakan salah satu hal terpenting dalam unsur suatu Negara hukum dikarenakan dalam suatu Negara hukum peraturan-peraturan yang akan dibentuk untuk warganya dibentuk pula oleh hukum. Dalam perkembangannya, antara warga dan Negara akan terjalin suatu hubungan timbal balik, yang mengakibatkan adanya hak dan kewajiban antara satu sama lain. Perlindungan hukum merupakan salah satu hak yang wajib diberikan oleh Negara kepada seluruh warganya.

Perlindungan hukum merupakan upaya melindungi subyek-subyek hukum melalui peraturan-peraturan yang berlaku dan dipaksakan pelaksanaannya dengan suatu sanksi. Perlindungan hukum dapat dibedakan menjadi 2 (dua), yakni :

1. Perlindungan hukum Preventif, adalah perlindungan hukum yang diberikan pemerintah dengan tujuan untuk mencegah sebelum terjadinya pelanggaran. Hal ini terdapat dalam peraturan perundang-undangan dengan maksud untuk mencegah suatu pelanggaran serta memberikan batasan dalam melakukan suatu kewajiban.

2. Perlindungan Hukum Represif, yakni merupakan perlindungan akhir berupa sanksi seperti denda, penjara, dan hukuman tambahan yang diberikan apabila telah terjadi sengketa atau telah terjadi suatu pelanggaran (Philipus M. Hadjon:38).

Oleh karena itu sesuai dengan pokok pikiran yang terkandung dalam asas Ketuhanan dalam sila 1 (kesatu) Pancasila dan pembukaan UUD NRI 1945, mewajibkan pemerintah dan penyelenggaraan negara untuk memegang budi pekerti yang luhur. Peraturan perundangundangan dan putusan-putusan 
hakim dalam urusan keagamaan wajib menghormati dan memperhatikan kaidah imperatif Pancasila, terutama sila 1 (kesatu) tiang pancang keberadaan agamaagama berasaskan Ketuhanan.

\section{A. KESIMPULAN}

Berdasarkan asas negara hukum Pancasila, dapat disimpulkan kedudukan agama dan keberagamaan, serta pengakuan dan perlindungan hukum terhadap kebebasan beragama di Indonesia memperoleh jaminan pengakuan dan perlindungan hukum oleh negara sepanjang tunduk dan mengikuti Konstitusi dan peraturan perundangundangan. Adapun mengenai bagaimana politik hukum pemerintah terhadap agama dan keberagamaan ke depan harus lebih responsif serta meningkatkan kajian-kajian tentang agama dan keagamaan agar penduduk Indonesia dapat menjalankan aktifitas keberagamaannya dengan bebas sesuai Konsitusi dan peraturan perundang-undangan, demi meningkatkan persatuan dan kesatuan bangsa Indonesia. Agama harus mampu memberi kontribusi bagi kemajuan bangsa, tidak hanya sekedar kebutuhan privat primordial tetapi juga memberi peran utama yang menghidupkan ruh dari falsafah Pancasila itu sendiri.

\section{B. REFERENSI}

\section{BUKU}

Abdillah, Masykuri, 2015, Islam dan

Demokrasi : Respons Intelektual Muslim Indonesia Terhadap Konsep Demokrasi 1966-1993, Media Group, Jakarta.

Amin, Samir, et.al, 2004, Dialog Agama dan Negara, PT LKiS Printing

Cemerlang, Yogyakarta.

Arif, Syaiful, 2016, Falsafah kebudayaan Pancasila : Nilai dan Kontradiksi Sosialnya, PT. Gramedia Pustaka Utama, Jakarta.

Arifin, Bustanul, 2001,

Transformasi Hukum

Islam ke Hukum

Nasional, Yayasan Al-

Hikmah, Jakarta.

Asshiddiqie, Jimly, 2009, Penghantar Hukum

Tata Negara, PT. Raja Grafindo Persada, Jakarta. 


,2010, Konstitusi
dan Konstitusionalisme
Indonesia, Sinar Grafika,
Jakarta.
,2015, Gagasan

Konstitusi Sosial :

Institusionalisasi dan

Konstitusionalisasi

Kehidupan Sosial

Masyarakat Madani,

Pustaka LP3ES, Jakarta. ,2015, Penguatan

Sistem Pemerintahan

dan Peradilan, Sinar

Grafika, Jakarta.

Atmadja, I Dewa Gede, 2015, Teori

Konstitusi \& Konsep

Negara Hukum, Setara

Press, Malang.

,2010, Hukum

Konstitusi

Problematika Konstitusi

Indonesia Sesudah

Perubahan UUD 1945,

Setara Press, malang.

Azhary, Tahir, 2003, Negara

Hukum : Suatu Studi

tentang Prinsip-

prinsipnya Dilihat dari

Segi Hukum Islam,

Implementasinya Pada $\begin{array}{lr}\text { Periode } & \text { Negara } \\ \text { Madinah dan } & \text { Masa } \\ \text { Kini, Prenada } & \text { Media } \\ \text { Group, Jakarta. } & \end{array}$

Azizy, Qodri, et.al, 2006,

Menggagas Hukum

Progresif, Pustaka

Pelajar, Yogyakarta.

Durkheim, Emile, 2011, The

Elementary Forms of

The Religious Life :

Sejarah Bentuk-bentuk

Agama yang paling

Dasar, terj. oleh Inyiak

Ridwan Muzir \& M.

Syukri, IRCiSoD,

Yogyakarta.

Effendy, Bachtiar, 2009, Islam dan

Negara, Graha

Paramadina, Jakarta.

El Muhtaj, Majda, 2005, Hak Asasi

Manusia dalam

Konstitusi Indonesia :

Dari UUD 1945 Sampai dengan Perubahan

UUD 1945 Tahun 2002,

Kencana Prenada Media

Group, Jakarta.

Hakim, Abdul Aziz, 2011, Negara

Hukum dan Demokrasi 
di Indonesia, Pustaka

Pelajar, Yogyakarta.

Hallaq, Wael B, 2013, Ancaman

Paradigma Negara

Bangsa : Islam, Politik,

dan Problem Moral

Moderenitas, terj. oleh

Akh. Minhaji, Suka-

Press, Yogyakarta.

Hamka, 2015, Keadilan Sosial

dalam Islam, Germani

Insani, Depok.

Husen, Laode, 2009, Negara

Hukum, Demokrasi, dan

Pemisahan Kekuasaan,

PT. Umitoha Ukhuwah

Grafika, Makassar.

Jafri, S.H Mohammad, 2012, Agama

dan Negara dalam

Pandangan Imam Ali :

Politik Islam yang

Bertumpu Pada

Masyarakat, Bukan

Negara, terj. Oleh Ilyas

Hasan, Rausyanfiqr

Institut, Yogyakarta.

Kaelan, 2013, Negara Kebangsaan

Pancasila : Kultural,

Historis, filosofis,

Yuridis, dan
Aktualisasinya, PT.

Paradigma, Yogyakarta.

Kholiludin, Tedi, 2009, Kuasa

Negara atas Agama :

Politik Pengakuan,

Diskursus Agama Resmi

dan Dikriminasi Hak

Sipil, RaSAIL Media

Group, Semarang.

Kusnardi, et.al, 1976, Hukum Tata

Negara Indonesia, $\mathrm{FH}$

UI dan CV Sinar Bakti,

Jakarta.

Latif, Yudi, 2015, Revolusi

Pancasila, Mizan

Pustaka, Bandung.

2014, Mata Air

Keteladanan : Pancasila

Dalam Perbuatan,

Mizan Pustaka, Bandung.

Maarif, Ahmad Syafii, 2017, Islam

dan Pancasila Sebagai

Dasar Negara : Studi

tentang Perdebatan

dalam Konstituante,

Mizan Pustaka, Bandung.

MD, Mahfud, 2009, Konstitusi dan

Hukum dalam

Kontroversi Isu, PT.

Raja Grafindo Persada,

Jakarta. 
, 2010, Membangun

Politik

Hukum,

Menegakkan Konstitusi,

PT. Raja Grafindo

Persada, Jakarta.

Menoh, Gusti A.B, 2015, Agama

Dalam Ruang Publik :

Hubungan Antara

Agama dan Negara

dalam Masyarakat

Postsekuler menurut

Jurgen Habermas, PT.

Kanisius, Yogyakarta.

Muthahhari, Murtada, 2012,

Masyarakat \&Sejarah :

Pandangan Dunia Islam

tentang Hakikat

Individu dan

Masyarakat dalam

Gerakan Sosial berbasis

Agama, terj. oleh Arif

Mulyadi, Rausyanfiqr

Institut, Yogyakarta.

Natsir, Mohammad, 2014, Islam

sebagai Dasar Negara,

Sega Arsy, Bandung.

Nonet, Philippe, et.al, 2015, Hukum

Responsif, terj.oleh

Raisul Muttaqien,

Nusamedia, Bandung.
Nusrati, Ali Asgar, 2003, Sistem

Politik Islam : Sebuah

Pengantar, terj. oleh

Musa Mouwasir, Nur

Al-Huda, Jakarta.

Prasetyo, Teguh, et.al, 2012,

Filsafat, Teori, dan Ilmu

Hukum : Pemikiran

Menuju Masyarakat

yang Berkeadilan dan

Bermartabat, PT. Raha

Grafindo Persada,

Jakarta. 2016, Sistem

Hukum Pancasila,

Nusamedia, bandung.

Qamar, Nurul, et.al, 2016, Sosiologi

Hukum, Mitra Wacana

Media, Jakarta.

Rahardjo, Satjipto, 2014, Ilmu

Hukum, PT. Citra Aditya

Bakti, Bandung.

Rawls, John, 2006, Teori Keadilan

:Dasar-dasar Filsafat politik untuk

Mewujudkan

Kesejahteraan Sosial

dalam Negara, terj. oleh

Uzair Fauzan \& Heru

Prasetyo, Pustaka

Pelajar, Yogyakarta. 
Setowara, Subhan, et.al, 2013, Agama dan Politik Moral, Intrans Publishing, Malang.

Smith, Huston, 2015, Agama-agama manusia : a Guide to Our Wisdom traditions, terj. oleh fx Dono Sunardi dan Satrio wahono, PT. Serambi Ilmu Semesta, Jakarta.

Soekarno, 2016, Filsafat Pancasila menurut Bung Karno, Media Press Indo, Yogyakarta.

Soemantri, Sri HRT, 2014, Hukum Tata Negara Indonesia : Pemikiran dan

Pandangan, PT. Remaja Rosdakarya, Bandung.

Syariati, Ali, 2011, Sosiologi Islam :

Pandangan Dunia Islam dalam Kajian Sosiologi untuk Gerakan Sosial Baru, terj. oleh Hamid Algar, Rausyanfiqr Institut, Yogyakarta.

Syarifuddin, Amir, 1990, Pembaharuan Pemikiran dalam
Hukum Islam, Padang Raya Angkasa, Padang. Thaib, Dahlan, et.al, 1999, Teori dan Hukum Konstitusi, PT. Raja Grafindo Persada, Jakarta.

Turner, Bryan S, 2012, Relasi Agama \& Teori Sosial Kontemporer, terj. oleh Inyiak Ridwan Muzir, IRCiSoD, Yogyakarta.

Unger, Roberto M, 2012, Teori

Hukum Kritis : Posisi

Hukum Dalam

Masyarakat Modern, terj. oleh Dariyatno dan Derta Sri Widowatie, PT. Nusamedia, Bandung.

Ward, Ian, 2014, Pengantar Teori Hukum Kritis, terj. oleh Narulita Yusron dan M. Khozim, Nusamedia, bandung.

\section{JURNAL}

Andrianih, Aan, Perlindungan Negara Terhadap Keyakinan Beragama bagi Masyarakat Hukum Adat Terkait 
Permasalahan

Kolom Agama

Pada Dokumen

Kependudukan,

Jurnal

Rechtsvinding

Online, Media

Pembinaan Hukum

Nasional BPHN.

Idami, Zahratul, 2016, Perlindungan

Hukum oleh

Negara Kepada

Pemeluk Agama di

Indonesia dan

Perbandingannya

dengan Ketentuan

dalam Islam,

Kanun Jurnal Ilmu

Hukum, Vol. 18,

No. 1, Banda Aceh. 